MedieKultur | Journal of media and communication research | ISSN 1901-9726

Article

\title{
The empowerment potential of public sector software (PSS)
}

\section{Pradip Ninan Thomas}

MedieKultur 2012, 52, 115-131

Published by SMID | Society of Media researchers In Denmark | www.smid.dk The online version of this text can be found open access at www.mediekultur.dk

Investigations into the potential for public sector software (PSS) to empower citizens are at a very nascent stage. This article explores the theoretical basis for, and practical advantages of, PSS, in the making of an informed and pro-active citizenry. Using the example of the emerging PSS movement in India and in particular the ICT literacy movement in Kerala, South India, it argues, that access to and use of software based on the principles of free and open source has the potential to contribute to an empowered citizenry. However the very concept of PSS is contested by major private software companies given that they stand to lose from public investments that are based on open standards. The article argues that PSS can contribute to the making of an information commons' and that the need of the hour is for innovative and creative solutions to the information deficits faced by communities in India and elsewhere.

\section{Introduction}

State responses to public services are complex and are often conditioned by the changing nature of political alignments, budgetary pressures and market-based rationalism. These responses, occasionally, go against the grain, and arguably public sector software is an example of a pro-active government policy that does have the potential to enable access to the use of information for all in the context of information and knowledge societies. One 
can argue that access to and affordable uses of such information can empower communities. The growing nature of digital literacy, and, in some parts of the world, the presence of active "recursive publics" in civil society, which have the capacity to make available and modify digital resources such as software, also increase the empowerment potential of new technologies. Furthermore, active alliances between the state and civil society, as in the case of India, in the creation, production and circulation of public sector software based on Free and Open Source principles, hold potential for the empowerment of communities in India.

In the context of India, the impetus for investments in public sector software (PSS) has come from the state in the context of e-governance and attempts to strengthen local manufacturing capacities. However, the underlying rationale and motivation for investing in PSS remains complex. In a country that is extraordinarily diverse and riven by economic, social, cultural and digital divides, the question of who will benefit from PSS remains a key issue. In my way of thinking, there are bound to be multiple beneficiaries, beginning with the State, which will benefit from cost efficiencies and streamlined e-governance, NGOs, associations and other publics, which will be in a position to innovate and facilitate local solutions, and connected citizens (admittedly still a small percentage of the population but that is growing), who will be in a position to take advantage of efficient information flows, for example in the context of filing Right to Information requests. While not all Dalits (untouchables), Adivasis (tribals) and poor Muslims (who are among the most economically backward) will benefit from PSS, the penetration of mobile telephony, even in remote parts of India, suggests that there will be scope for new PSS-based, mobile applications. At the very same time, one can also argue that there are bound to be negative consequences of PSS, including the fact that it could increase the surveillance power of the State. Unfortunately, such complexities that stem from the nature of the digital have to be factored in, and I argue that despite the knotty, multi-faceted consequentialities of PSS, it does also have the potential to empower. I would also like to categorically state that PSS needs to be viewed in terms of its functional and creative potential rather than in terms of it being an all-sufficient, substitute or panacea, given that it will take more than any given technology to bring about lasting social change in India.

This article will 1) briefly explore the concept of public sector software, 2) theorise PSS in relationship to the Risk Society and the Commons, 3) highlight the relationships between the State and PSS in Kerala, India, focussing on the IT@Schools project, and 4) address the legal and political challenges faced by PSS.

\section{The climate for public sector software (PSS) in India}

Close to Rs 10,000 crores (USD \$2 billion) has been allocated for e-governance under the National E-Governance Plan (NeGP) in India. This is just one investment among many made by the state and central governments in e-governance schemes, in addition to five-year plan investments in the provisioning of broadband, rural connectivity and nation-wide e-gover- 
nance projects, investments in a range of public sector IT institutions, including the National Informatics Centre (NIC), Centre for the Development of Telematics (C-DOT), Centre for the Development of Advanced Computing (C-DAC), Department of Information Technology, National Institute for Smart Government (NISG), and projects such as the multi-billion dollar rural broadbanding initiative under the National Knowledge Commission and the Public Information Infrastructure initiative, among very many other projects. The vision of the NeGP is as follows: "Make all Public Services accessible to the common man in his locality, through common service delivery outlets and ensure efficiency, transparency and reliability of such services at affordable costs to realize the basic needs of the common man." The scale of these investments in public information projects raises a number of very interesting questions related to ownership and control, but also related to access, the philosophical basis for such provisioning, and the consequences of such investments in a global context characterized by a retreat from state investments in public services.

In a concept note prepared by one of the key NGOs in India involved in the campaign for public sector software, IT for Change (Software Principles for the Public Sector with focus on Public Education, February 1-2, 2010, Bengaluru, Workshop Report), this initiative is defined as follows:

\begin{abstract}
Public software can be defined as software developed for the public good, which is publicly owned. Public ownership also implies that it cannot be privatized or privately owned. It is freely shareable and customizable and hence is basically Free and Open Source Software. Public software is of two kinds: 1. Public Software developed to promote public good that helps government (public sector) to fulfil goals of government - software that supports NREGA (National Rural Employment Guarantee Act) transactions in a transparent manner; 2. Public Software itself as a public good - new digital goods such as Wikipedia where the software itself performs public interest functions. Public Sector for the purpose of these guidelines is defined broadly as comprising of institutions working for public interest. While this includes not only governments but also academic institutions, civil society ( $\mathrm{NGO} / \mathrm{CBO}$ ), community media institutions etc., there is a special role for the government as the key public sector actor in promoting public software.
\end{abstract}

\title{
Some reasons for investments in this sector
}

The moves to explore the possibilities for public sector software were precipitated by 1) the realisation of the breadth and depth of public sector investments in the digital revolution, inclusive of the informationalisation of services and infrastructure development, 2) recognition of the critical roles played by information and knowledge in society and the economy, 3) evidence of vendor lock-in, particularly the overwhelming presence of a single, dominant, software player in the public sector, i.e., Microsoft, and the financial costs associated with licensing that are related to the political economy of intellectual property (IP), 4) the 
growing recognition of the strengths, particularly access to software code, interoperability, flexibility and acknowledgement of the lower costs associated with Free and Open Source Software (FOSS), 5) the billions of dollars' worth of investments in e-governance and issues related to software deployment and access to information, and 6) broader public domain issues articulated by champions of open access both within and outside of the public sector in different parts of the world. The EU Directive of 17 November 2003 (http://eurlex. europa.eu/LexUriServ/LexUriServ.do?uri=CELEX:32003L0098:EN:HTML) on the re-use of public sector information, while strongly focussed on the commercial exploitation of this data, provides information on the extent of public sector data and possibilities for its re-use:

(4) The public sector collects, produces, reproduces and disseminates a wide range of information in many areas of activity, such as social, economic, geographical, weather, tourist, business, patent and educational information.

(5) One of the principal aims of the establishment of an internal market is the creation of conditions conducive to the development of Community-wide services. Public sector information is an important primary material for digital content products and services and will become an even more important content resource with the development of wireless content services. Broad cross-border geographical coverage will also be essential in this context. Wider possibilities of re-using public sector information should inter alia allow European companies to exploit its potential and contribute to economic growth and job creation.

A fundamental reason for a more pro-active approach adopted by governments to establishing the presence of public sector software can be attributed to the recognition of vendor lock-in and costs associated with licensing and upgrades. As Bob Griffith (2003, p. 24) observes in the case of the UK, this shift accentuated soon after the change in Microsoft's licensing policy towards an annual license and expenditures on licensing. "There are about 850,000 PCs in use in the local authority sector in the UK. Many of these run Microsoft. That represents a lot of money and explains why IT managers have started to pay this area a great deal more attention and to consider the possibilities presented by open source software" (see also Waring \& Maddocks, 2005). The public sector in countries and blocs in the developed world, including the US, the EU, Japan, South Korea and the developing world, including India, China, Peru, Venezuela, Brazil, Thailand, among other countries, are now open to procurement processes that also include FOSS and exhibit a variety of FOSS deployment intensities, varying from high, as in Brazil, to the relatively low, as in the US, although of late the military establishment in the US has invested significantly in FOSSbased alternatives. Estimates of annual savings related to switchovers from Windows in the public sector are as high as USD 120 million (Kingstone, 2005) in Brazil to USD 10.5 million by the IT@School Project in Kerala, India (see De, 2009), to a more modest GBP 105,000 by the Birmingham City Council (Broersma, 2006). Baguma (2006), in a chapter on FOSS in e-governance in Uganda, clarifies the nature of these savings: 
OSS/FS can be obtained free of charge or at a far cheaper cost, where a manufacturer charges for the packaging/distribution....Apart from that no loyalty or licence fees apply and one copy is enough for unlimited installations and distribution. The options are using Linux at UGS 2,000/= equivalent to USD 1.2 (cost of CD) or buying Microsoft Windows XP at UGS 100, 000, equivalent to USD 59. Linux saves UCS 98,000 (USD 58) and one copy is enough for multiple installations. An office desktop computer will need 3 other products minimum at the same price or higher, coming to $100,000 \times 4=$ UGS $400,000 /=$ on software only, whereas for OSS/ FS, these products come bundled with the operating system, and if not can be obtained free of charge. ...This makes OSS/FS a far more cost-saving option as opposed to proprietary solutions (Baguma, 2006, p. 203).

Apart from costs, the ability to create flexible solutions, iron out bugs, strengthen security and to freely innovate and adapt software are additional reasons for the adoption of FOSS by the public sector.

\section{Risk, public sector software \& e-Governance}

Software projects in the public sector are often high-risk initiatives given the complexity of their deployment over large sectors, for example the National Health Service (NHS) in the UK, which is the largest supporter of health care in that country, with over a GBP 100 billion budget in 2009. Paul Bannerman (2007; see also Bronte-Stewart: undated) highlights some of the risks associated with public software initiatives:

International surveys suggest that only about a quarter of software projects succeed outright (that is, they complete as scheduled, budgeted and specified), and that billions of dollars are lost annually through project failures or projects that do not deliver promised benefits. No consolidated data is available on software project performance in public sector agencies. However, evidence suggests that this is a global issue, impacting public and private sectors alike (Bannerman, 2007, p.1).

While the implementation of public software projects lends itself to risk analysis, one can argue that PSS as a public good, mitigates the risk associated with the outsourcing of "welfare" and the inherent danger of large amounts of private data falling into the hands of commercial entities. I see risk therefore primarily in terms of the dependency and control that can be exerted by firms that have the power to dictate the very shape and nature of products, processes and outcomes associated with public software. Federspeil and Brincker (2010, p. 41) employ the German political theorist Ulrich Beck's notion of the "Risk Society" to understand current anxieties related to software standards in Denmark, a country that on January 1, 2008, passed a resolution that supported open standards for all public sector software. As they point out:

Bearing in mind Beck's definition of risk, software lends itself to risk analysis: The software market transcends national states - in fact, national states are apparently quite unable to 
regulate or control this market. The software market produces and delivers products on which the public sectors are completely dependent. This is particularly evident in countries like Denmark where the public sector has undergone digitalisation. Finally, one cannot insure against data losses, malfunctioning electronic filing systems, or breakdowns in communication infrastructures, the consequences of which are difficult to quantify and thereby compensate in monetary terms. Therefore, the risks associated with software may be characterised as incalculable.

Beck's understanding of "risk" is based on the various environmental hazards facing the globe in the context of late modernity and in a situation characterised by the globalisation of risk best illustrated by catastrophes such as Chernobyl and the relative powerlessness of the state to deal with the intended and unintended consequences and risks associated with progress and growth. Beck (1999) describes the change in the power of the nation state thus:

The national state is a territorial state; its power is grounded upon controlling the membership, defending the borders, laying down the laws for a particular place. The world society created by globalisation cuts across national state boundaries, not only economically, but through a multiplicity of social circles, communication networks, market relations and lifestyles, none of them specific to any locality (Beck, 1999, p. 25).

The network society's harmonisation of data flows - economic, political, cultural and social - certainly contributes to the strengthening of faith in the ability of global capitalism to contribute to growth and progress. However, this hope and certainty is offset by issues related to the security of data flows, and the inability to control these flows given the "uncontrollable" nature of the digital. In this sense, as Cottle $(1998$, p. 8) has observed: "The nature of contemporary 'risks' for Beck are historically unprecedented in terms of their spatial and temporal reach, their potential catastrophic effects and, importantly, their invisibility". While there is no denying the tremendous contributions by the services sectors to growth in India, how to manage this growth without endangering the security and sovereignty of the nation is an issue that is of concern to the Indian government. e-Governance has already begun to generate vast amounts of data on the public, and public sector software is a way of ensuring that this data is managed primarily in support of the national interest. While the draft National Policy on Open Standards in e-Governance (2009) does acknowledge security concerns in clause 4.7, its specific objectives as outlined below support the national interest:

The National Policy is designed to ensure appropriate Information Technology adoption that promotes the interests of the nation with level playing field to all. In particular, it aims at the following:

3.1 Promote innovations and entrepreneurship in e-Governance at grassroots level of the society, spread across the geographical limits of the country. 
3.2 Ensure availability of multi-lingual e-Governance services.

3.3 Ensure reliable long term accessibility to public documents and information

3.4 Ensure cost effective e-Governance services.

3.5 Provide larger spectrum of choice of solutions and flexibility to users of e-Governance systems by avoiding vendor lock-in.

3.6 Provide better and fair opportunities to all vendors in e-Governance eco system by enhancing interoperability.

One can argue that public sector software mitigates the risk of "organised irresponsibility". Here again, Ulrich Beck's (1997, p. 29) suggestion of the need for a "relations of definition" is useful because it refers to the role played by "rules, institutions and resources" in the mitigation of such risks. The following four questions can be applied to understanding risk, not only in terms of e-governance but all "development" projects supported by the state and the private sector in the context of contemporary India:

(1) Who, that is, what social agency and authority establishes in what way how harmless or dangerous products and their side-effects are? Does the responsibility lie with those who create and profit from the risks, or with those who are currently or potentially affected, or with public agencies? (2) What type of knowledge or unawareness of causes, dimensions, agents and so on is consulted or acknowledged here? Who bears the burden of proof? (3) What is considered 'sufficient proof'? And this, of course, must be answered in a world where all knowledge of hazards and risk moves in the presuppositions of probability theory. (4) Where hazards and destruction are recognised and acknowledged, who decides issues of liability, compensation and costs for the affected parties, and who rules on appropriate forms of future monitoring and regulation?

Control over domain specific data can lead to its commercial exploitation and compromise privacy and security resulting in digital and other divides. It can be argued that the payment of license fees, lack of access to the source code, lack of competition, inability to innovate or reuse software is, from a public perspective, a case of "organised irresponsibility".

\section{The public domain, the commons and the state}

Yochai Benkler (1998), in one of the early studies of the informational commons, describes it in the following words:

'The commons' refers to institutional devices that entail government abstention from designating anyone as having primary decision-making power over use of a resource. A commons-based information policy relies on the observation that some resources that serve as inputs for information production and exchange have economic or technological characteristics that make them susceptible to be allocated without requiring that any single organization, regulatory agency or property owner, clear conflicting uses of the resource. For example, the non-rival nature of information, and the perfect renewability of radio fre- 
quency spectrum create the possibility of sustainable commons in information used as an input into new information production, and in the RF spectrum, respectively. The commons approach builds around such inputs a regulatory framework that takes advantage of their peculiar economic or technological characteristics to make the resources freely available to all, and free of the unilateral control of any organization, be it governmental or nongovernmental (Benkler, 1998, p. 2).

Benkler's interpretation of the commons is inflected by a perspective that perhaps can be considered "quasi-libertarian", although he does consider the need for a regulatory approach to the commons. The informational commons very much like the physical commons - the sea, parks, and the atmosphere - is viewed as an arena that can be managed and controlled by multiple stakeholders rather than by a single organisation, be it governmental or private.

At the heart of the debate related to the commons is a very simple notion. How can a resource - be it parks or digital information - be managed in such a way that it offers a majority maximum benefits; benefits that can be of an economic, social, cultural and political kind. For the commons, is not just the opportunity for us as citizens to sit and enjoy the ambience and serenity of a national park, but also to use freely available, non-rivalrous resources, such as knowledge in the public domain in the pursuit of creativity. The cost of a 30 second excerpt from a 1980s Bollywood song for use in a digital mix may be as much INR 5.5 lakh (USD 14,000) in a proprietorial system. Or such music can be made available in the public domain or at least be part of knowledge management systems that people can access for less onerous sums. David Bollier (2007) explains that:

...the language of the commons...provides a coherent alternative model for bringing economic, social, and ethical concerns into greater alignment. It is able to talk about the inalienability of certain resources and the value of protecting community interests. The commons fills a theoretical void by explaining how significant value can be created and sustained outside of the market system. The commons paradigm does not look primarily to a system of property, contracts, and markets, but to social norms and rules, and to legal mechanisms that enable people to share ownership and control of resources. The matrix for evaluating the public good is not a narrow economic index like gross domestic product or a company's bottom line but instead looks to a richer, more qualitative and humanistic set of criteria that are not easily measured, such as moral legitimacy, social consensus and equity, transparency in decision making, and ecological sustainability, among other concerns (Bollier, 2007, p. 29).

That the idea of the commons is making a comeback in a number of domains - the environment, the economy, culture - is significant and would seem to suggest that there is greater appreciation of and value for commons-based solutions in our world today. Certainly, that the 2009 Nobel Prize for economics was shared by Oliver E. Williamson and Elinor Ostrom, a champion of the commons, indicates that the commons-based approaches to production and consumption now present a serious alternative to conventional market-based eco- 
nomics. The International Association for the Study of the Commons biennial conferences, most recently held in Hyderabad, in January 2011, is another indication of growing interest in both the theory and practice of the commons (see the IASC Website). This recognition of the value of the commons in the $21^{\text {st }}$ century has been accompanied by a critique of anti-commons literature, most notably Garrett Hardin's (1968:1244) piece on the "Tragedy of the Commons", in which the author, taking a Malthusian line, had stated the case that the freedom to breed (human and animal), along with selfish human behaviour, placed intolerable limits on the commons, such as pasture land. Using the selfish individualist, economics-based behaviour of a herdsman to continually add flock in a pasture where all other herdsmen do the same, Hardin argued thus:

...this is the conclusion reached by each and every rational herdsman sharing a commons. Therein is the tragedy. Each man is locked into a system that compels him to increase his herd without limit - in a world that is limited. Ruin is the destination toward which all men rush, each pursuing his own best interest in a society that believes in the freedom of the commons. Freedom in a commons brings ruins to all.

While over-use and over-harvesting of resources certainly are contemporary problems, critics have pointed out various examples of human beings in different parts of the world managing the sharing of resources, following varieties of "co-operative individualism", resulting in economic prosperity and sustainability over time. Schlager and Ostrom (1992) describe the rights and responsibilities (duties) associated with common-pool resource management as follows:

Access: The right to enter a defined physical property.

Withdrawal (later termed Extraction): The right to obtain the 'products' of a resource (e.g., catch fish, appropriate water, etc.)

Management: The right to regulate internal use patterns and transform the resource by making improvements.

Exclusion: The right to determine who will have an access right, and how that right may be transferred.

Alienation: The right to sell or lease either or both of the above collective-choice rights (Schlager \& Ostrom, 1992, pp. 250-251)

An equally influential phrase that directly relates to the present-day reality of enclosures around information/knowledge is that of the "tragedy of the anti-commons", enunciated by Michael Heller (1998) in the Harvard Law Review. Using empty stores in Moscow as a way of describing an inefficient use of resources by a state that had sold rights to too many owners who held no commonality of purpose, Heller described this tragedy as follows: 
... 'anticommons property' [is] a property regime in which multiple owners hold effective rights of exclusion in a scarce resource....A tragedy of the anticommons can occur when too many individuals have rights of exclusion in a scarce resource. The tragedy is that rational individuals, acting separately, may collectively waste the resource by underconsuming it compared with a social optimum (Heller, 1998, pp. 668-677, emphasis added).

Adding to this description of the anti-commons, one can also suggest that the anti-commons is the consequence of extreme concentrations - as for example, Microsoft's worldwide control over basic systems software used in PCs and laptops that is the result of aggressive IP contestations and the bundling of software that effectively shut out competition, along with proprietorial, global intellectual property (IP) regimes and trade and corporate lobbies, such as the World Trade Organisation (WTO), the World Intellectual Property Organisation (WIPO), the Motion Picture Association of America (MPAA), the Business Software Alliance (BSA) and other lobbies that have effectively placed enclosures around the possibility of information/knowledge in the public domain.

While there definitely is merit in such an approach, including the advantages of cooperative resource management, ownership and decision making, its universal application does have limitations given the differing manifestations of the state and inflections of democracy found in the world. In the case of India, the state plays an extraordinarily ambivalent role as both a protector of democracy as well as its chief antagonist. In a context in which close to 350 million people live either in absolute or relative poverty, the state's role as a public benefactor is second to none given that it supports both lives and livelihoods of vast numbers of people. While the state has certainly presided over the destruction of the commons in India, it continues to play a vital role in protecting it, sometimes in unexpected ways. An example of the latter is the "Chennai Sangamam" festival organised by the government of Tamil Nadu in South India during the Pongal (harvest festival), in mid-January, when public parks throughout the city (that are often poorly maintained throughout the country), become the location for simultaneous, free, multi-religious, inclusive cultural festivals involving 4,000 performances, which have led to the regeneration and revival of dances and local cultural traditions on the edge and to the celebration of the park, the street and beaches as a vital aspect of the urban commons. That the NGO involved in this event has been accused of being a channel for tainted kickbacks linked to a recent telecommunications scam, suggests that there well might be, in certain circumstances, links between the development of the commons and populist political projects. This instance of what one may term the "reinvention of the commons" is an aspect of a tradition of the commons that has existed for millennia in South Asia and elsewhere. Specific traditions related to water, forest and land management, managed by local communities, have been a part of the history of the commons in India. As the commons activist and researcher N. S. Jodha explains in an interview with Ruchi Ghate (2010): 
In the South Asian context, common property can apply to a wide variety of resources: village woodlands, pastures, uncultivable ('waste') lands, irrigation tanks, watershed drainage, water flows and their banks, and fisheries, among others. CPRs are vital for income and employment generation through off-season activities, for drought-period sustenance, additional cropping, handicrafts and petty trading. There are also larger social and ecological gains, such as resource conservation, space for rich biodiversity, drainage stability and groundwater recharge, sustainability of diversified farming systems, low-cost sustenance support to poor households and renewable resource supplies.

The specific example of public sector software is arguably also a case of the state's involvement in enlarging the informational/knowledge commons, thereby strengthening the public domain, meaning a space that is free from any form of enclosure associated with privatisation. The development of bio-diversity registers in villages in Kerala and Andhra Pradesh and patent-free zones are examples of community-based public domains. Anuradha (2001) describes the purpose and the means by which the public domain is maintained:

The Register processes documents of community and individual knowledge of occurrence, practices of propagation, sustainable harvests and conservation, as well as economic uses of biodiversity resources. All information accumulated in the Register can be used or distributed only with the knowledge and consent of the local community, so that it is in a position to refuse access to the register and to set conditions under which access would be allowed. The community, while consenting, can charge fees for access to the Register and collection of biological resources. Decisions on how to disburse the funds are to be made through village community meetings.

One can argue that such initiatives will be strengthened through the availability of public sector data on local environments.

\section{PSS and the state: An example from Kerala, South India}

The southern Indian state of Kerala, in many respects, has been at the forefront of experimenting with the project of substantive democracy in India. Kerala has been globally lauded for its social indices - including women's literacy and health that has been consistently above national averages - and for its many projects linked to participatory planning in development. Much of Kerala's "social" successes can be put down to its unique political history and traditions of advocacy supported by a number of passionately committed civil servants and civil society activists. So in some ways it is not surprising that this state is also involved in citizen-focussed, FOSS-based solutions through a variety of public sector projects, notably in education. The Kerala government's 2007 IT Policy (2007:4) is intentional in its advocacy of, and preferential option for FOSS, and explicitly states that one of its objectives is to become a global centre for FOSS through the establishment of an International Centre for Free Software and Computing for Development: "2.10 The Government realizes 
that Free Software presents a unique opportunity in building a truly egalitarian knowledge society. The Government will take all efforts to develop Free Software and Free Knowledge and shall encourage and mandate the appropriate use of Free Software in all ICT initiatives". The Centre for Advanced Training in Free and Open Source Software (CATFOSS) set up by the government is involved in both FOSS training and the development of low cost software solutions.

Public support for FOSS-based solutions has translated into numerous practical projects. The FOSS-based IT@School project in Kerala for example has led to ICT-enabled education in 8000 schools in the state and has involved the training of 160 master trainers and 5600 IT coordinators (selected from teaching staff). The IT@School Project began in 2000 and its major aim was to impart IT-enabled education. The publically owned software has been bundled into a single CD for a one point installation - not achievable in the context of the use of proprietary software. The Operating System in use in all government aided schools in the State is the IT@School GNU/Linux/Ubuntu system. What is perhaps the most significant aspect of this project is that there has been a massive investment in teachers and students as co-learners and foot soldiers of FOSS in Kerala. From the very beginning, there was a strong commitment to teachers and students taking responsibility for the development of FOSS. This was an important innovation given that the norm in IT in education projects is for outside consultants and/or vendor employees to fix bugs and malfunctioning hardware and software. Such dependence can be costly both in terms of time and expenditure and this accent on "disintermediation" is one of the most important characteristics of this project. Mobile hardware clinic teams regularly visit schools. As Kasinathan (2009) explains in a Policy Brief:

The program has created 'mobile hardware clinic' teams, which regularly visit schools for inspection, checking hardware and doing most of the required maintenance and repair work. A policy of cannibalising computers that cannot be repaired has two benefits; it substantially lowers costs of maintenance while ensuring higher uptime. Teachers are trained to install software and to also do routine software upgrades. The program disproves a commonly held belief that school teachers in India's public education system are not capable of, and/or are unlikely to be interested in, engaging with ICTs beyond being simple users (Kasinathan, 2009, p. 2).

I would argue that this approach is in many ways in the Freirean tradition with its accent on demystifying technology, enabling users to understand how it works and getting people to use software for their own ends - in this case in the context of secondary education. Just as significant, the story of FOSS in Kerala is that of people realising that software is a tool that can and should be adapted to local ends and that knowledge making is a process involving teachers, students and technology. Hardware clinics and content development classes are frequently held and the School wikis help in the creation of collaborative content. Not only has FOSS been customised to teachers' needs, it is available in Malayalam, the local 
language and all material is owned by the public and is shareable. The teachers have been involved in the creation of content, and a number of FOSS-based applications have been customised. These include Dr. Geo and Geogebra for Mathematics, Rasmol, Chemtool and Kalzium for Chemistry, K-tech lab for Physics and Marble, KStars, XrMaps for Geography. An equally important outcome of this initiative is the training of women master trainers. Given that 67 per cent of school teachers in Kerala are women, a number of them became master trainers and familiar with strong skill sets. As an article on gender in the IT@Schools project (Raji \& Arun, 2009) notes:

\begin{abstract}
Master Trainers have skills that are on par with those of IT technicians. Their skill sets include basic administration of computers with GNU/Linux operating systems, installation and troubleshooting of computer hardware and software, setting up of small office network, connecting to the Internet and using various specialised software. They have also developed strong managerial capacity as each of them manage IT implementation in 22-30 schools, arrange and execute training programmes for teachers and support the implementation of various e-governance programmes of the Education Department.
\end{abstract}

In the case of this project, the use of FOSS-based solution has saved the government USD 2.27 million that otherwise would have been expended on licensing proprietorial software (see le Fevre, 2009).

Another project that highlights the potential of FOSS-based solutions is the Insight project, a joint initiative between the government of Kerala and an NGO, Society for Promotion of Alternative Computing and Employment (Space), which is specifically focussed on developing software for the differently abled, especially for the visually impaired. One of the better examples of solutions is the screen reader software ORCA that is available for free to the visually impaired at no cost compared to its proprietary counterpart that is costs around INR 55,000 (USD 1,100).

\title{
Public software challenges
}

While there are, at any given time, a number of e-governance initiatives in India that are powered by public sector software solutions, such as NRCFOSS/C-DAC's Linux-based Bharat Operating System Solutions (BOSS), there are inter-state variations in the deployment of such solutions. While the Southern states, particularly Kerala, and to lesser extent Tamil Nadu and Karnataka, have adopted such solutions, along with Gujarat, Orissa, West Bengal and Assam, a number of states in North and Central India have yet to follow suit. The Government of Assam's Information technology Policy (2009), for example, specifies FOSS as the basis for public sector software: 
3.12 FREE AND OPEN SOURCE SOFTWARE POLICY:

(a) The Government would promote use of Free and Open Source Software (FOSS) in all the departments and State agencies, bodies and authorities.

(b) The State Government would promote manpower development and training in use of FOSS, especially in day to day office works.

(c) The State Government would promote imparting training on FOSS in schools and colleges.

(d) Entrepreneurs/companies using FOSS for application/website development would be given preference over those using third party packaged applications.

(e) All source codes customized and developed for any State Government body shall be duly archived in a repository, and shall be made available freely to other Government departments.

(f) The Government departments and bodies would ensure that Open Document Format (ODF) is adhered to in creating and storing editable documents, data and information and all applications developed by the respective departments adhere to ODF and other Open Standards and are largely independent of Operating Systems (OS) and web browsers.

(g) The Government departments and bodies would ensure that any generic hardware procured has support for multiple Operating Systems (OS) such as Unix, Linux, OpenSolaris and other open source platforms (2009, pp. 1216-1217.

While a lack of awareness of FOSS-based solutions does exist, more formidable issues are pre-existing lock-ins and tie-ups that dominant software players such as Microsoft have with state governments in India. In the state of Maharashtra, for example, the Department of Education and Microsoft have entered into a contract whereby Microsoft will set up IT academies and train teachers at no cost to the state and where even curriculum design will be handled by Microsoft. Trade bodies such as NASSCOM and MAIT have also played a role in trying to water down the Draft Policy on Open Standards for e-Governance by lobbying for multiple standards and royalty encumbered standards.

One of the major issues facing the public sector software movement is the fact that they are involved in both "reacting" and responding to the reality of multiple standards and issues with interoperability in e-governance projects and the politics of resistance to change at government levels, as well as proactively lobbying for a more focussed, intelligent, centralised approach to public sector software development in India. The silo approach to departmental management affects the sharing of content and this is a major concern in India, where consanguineous units act as if they are unrelated. The lack of UNICODE compliant fonts for example has led to compatibility issues. While there are a number of initiatives in India that are looking to deliver on free software Unicode typefaces, much more work needs to be done in this regard. The lack of training in FOSS and resistance to FOSS in the public sector are also issues that public sector software enthusiasts have to contend with. 


\title{
Conclusions
}

While it is clear from examples such as the deployment of FOSS-based PSS in the state of Kerala, India, and data mash-ups in the UK, that PSS and the making available of public data can contribute to innovation, creativity and empowerment; but it would seem that what is required is not the embrace of a singular solution, as for example, PSS, but a re-valuation of existing models, be it market or state based along with the valuation of new approaches to software deployment for development based or mixed solutions.

\begin{abstract}
Instead of blind faith in private ownership, common-property institutions, or government intervention, scholars need a better understanding of: (1) the conditions that enhance or detract from the emergence of more efficient property-rights regimes related to diverse resources, (2) the stability or instability of these systems when challenged by various types of exogenous or endogenous changes, and (3) the costs of enforcing regulations that are not agreed upon by those involved. Further, the performance of property-rights regimes in field settings needs to be compared to other regimes in field settings. No real-world institution can win in a contest against idealized institutions. The valid question is how various types of institutional arrangements perform comparatively when confronted with similarly difficult environments (Schlager \& Ostrom, 1992:260).
\end{abstract}

However, I would argue that a forward looking approach to digital knowledge management, production and distribution in development simply must come to terms with the nature of the digital and access based on open source and open standards. While the transformation of Gov. 1.0 to Gov. 2.0 ostensibly signals a new commitment to citizen orientation in the context of the network society, there is a need for empirical information on whether indeed this laudable objective has led to the desired results. There are doubts as to whether such investments are motivated by the desire to implement governance or whether these are merely the latest examples of information-led governmentality, to use a Foucaultian term that describes the ways in which the technologies of power, self and market mediate government and the governed. Investments in national identity schemes, such as, the Unique Identification Scheme in India, are an example of governmentality with the potential to increase surveillance of the "common man" in India. Having said this, the public desire to create "communities of practice" via access to and use of public knowledge is an evolving global issue. Wenger, McDermott and Snyder (2002) describe three elements that make up any given community of practice: "...a domain of knowledge, which defines a set of issues; a community of people who care about this domain; and the shared practice that they are developing to be effective in their domain" (p. 27). It would seem that PSS does offer new possibilities for creating many communities of practice, thus increasing empowerment and spaces and possibilities for social change. 


\section{References}

Anuradha, R.V. (2001). Biopiracy and traditional knowledge, Earthscapes: The Hindu Folio, May 20. Retrieved November 21, 2010 from: http://www.hinduonnet.com/folio/fo0105/01050380.htm

Baguma, R. (2006). Affordable E-governance using free and open software. In Williams and Baryamureeba (Eds.), Information and Communication Technology for Sustainable Development: Measuring Computing Research Excellence and Vitality (pp. 199-208). Kampala: Foundation Publishers. Also available at: http://cit.mak.ac.ug/iccir/downloads/SREC_05/Rehema\%20Baguma_05.pdf

Bannerman, P. (2007) Software project Risk in the Public Sector. In Proceeding of the 2007 Australian Software Engineering Conference (ASWEC'07), IEEE (pp. 1-10). Retrieved, December 8, 2011 from: http:// ieeexplore.ieee.org/stamp/stamp.jsp?tp =\&arnumber $=4159691$

Beck, U. (1999). Beyond the nation state. The New Statesman, December 6: 25-27.

Beck, U. (1997). Global Risk Politics. The Political Quarterly, 68, B: 18-33.

Benkler, Y. (1998). The commons as a neglected factor of information policy (pp. 1-28). Retrieved, November 21, 2010 from: http://www.benkler.org/commons.pdf

Bollier, D. (2007). The growth of the commons paradigm. In Hess, C. \& Ostrom, E. (eds.), Understanding Knowledge as a Commons: From theory to practice (pp. 27-40). Cambridge, Mass.: MIT Press.

Bollier, D. (undated). Unleashing Public Sector Information. On the Commons. Retrieved, January 31, 2011 from: http://onthecommons.org/unleashing-public-sector-information

Broersma, M. (2006) Birmingham City Council claims open source success, Techworld, November 30. Retrieved November 21, 2010 from: http://news.techworld.com/operating-systems/7459/birmingham-city-council-claims-open-source-success/

Bronte-Stewart, M. (undated). Developing a risk estimation model from IT project failure research. Retrieved, December 8, 2011 from: http://cis.uws.ac.uk/research/journal/V9/V9N3/failure.doc

Cottle, S. (1998), Ulrich Beck, 'Risk Society' and the Media: A Catastrophic View? European Journal of Communication, 13(5): 5-32.

De, R. (2009), Economic Impact of free and open source software: A study in India. Presented at Interop, Mumbai, October 7-9. Retrieved November 21, 2010 from: http://www.slideshare.net/InteropMumbai2009/rahul-de-economic-impact-of-free-and-open-source-software-a-study-in-india-interopmumbai-2009

Directive 2003/98 of the European Parliament and of the Council of 17 November 2003 on the re-use of public sector information. EurLex. Retrieved, February 1, 2011 from: http://eurlex.europa.eu/LexUriServ/LexUriServ.do?uri=CELEX:32003L0098:EN:HTML

Draft National Policy on Open Standards for e-Governance (2009). Retrieved September 28, 2010 from: http://fosscomm.in/OpenStandards?action=AttachFile\&do=get\&target=Policy_On_Open_Standards_V2.pdf

Ensuring adoption of progressive national eGovernance standards policy, IT for Change. Retrieved, September 28, 2010 from: http://www.itforchange.net/component/content/article/220-open-standardscampaign.html

Federspiel, S.B. \& Brincker, B. (2010). Software as Risk: Introduction of Open Standards in the Danish Public. The Information Society, 26(1): 38-47.

Ghate, R. (2010). South Asia commons are weakening: Interview with N.S. Jodha. Himal South Asia, October. Retrieved, November 23, 2010 from: http://www.himalmag.com/-Southasia-s-commons-areweakeningnw4738.html

Griffith, B. (2010). Public Sector IT Chiefs favour Open Source. Computer Weekly, October 28: 24.

Hardin, G. (1968). The Tragedy of the Commons. American Association for the Advancement of Science, 162(3859): 1243-1248. 
Kingstone, S. (2005). Brazil adopts open-source software. BBC Online, June 2. Retrieved November 21, 2010 from: http://news.bbc.co.uk/2/hi/4602325.stm

Heller, M.A. (1998). The tragedy of the anticommons: Property in the transition from Marx to markets. Harvard Law Review, 111(3): 621-688.

Hoffman, N. (2009). Preserving state government digital information Minnesota Historical Survey: Mashups using Government data, A White paper (pp. 1-13). Retrieved January 31, 2011 from: http:// www.mnhs.org/preserve/records/legislativerecords/docs_pdfs/DataMashups1.pdf

Information Technology Policy of Assam (2009, August 04). The Assam Gazette. Retrieved, September 28, 2010 from: http://assamgovt.nic.in/pdf/ITPOLICY-2009-Final-Gazette-Style.pdf

International Association for the Study of the Commons $13^{\text {th }}$ Biennial Conference: Sustaining Commons, Sustaining our Future, Hyderabad, January 10-14, 2011. Retrieved December 10, 2011 from: http:// iasc2011.fes.org.in/about-iasc.php

Insight: ICT for Differently Abled. Retrieved, December 7, 2011 from: http://insight.kerala.gov.in/about/

Kasinathan, G. (2009). ICTs in School Education-Outsourced versus Integrated Approach, Policy Brief. Bangalore: IT for Change.

Kerala Information Technology Policy (2007). Towards an Inclusive Knowledge Society. Retrieved, December 7, 2011 from: http://www.catfoss.kerala.gov.in/pdf/ITPolicy-2007.pdf

Le Fevre, J (2009). Open source software saves Indian IT@Schools \$2 million. Thaindian news, July 23. Retrieved, December 7, 2011 from: http://www.thaindian.com/newsportal/tech-news/open-sourcesoftware-boosts-indian-itschools-program_100222131.html

NeGP Vision Statement, India Development Gateway: E-Governance. Retrieved November 21, 2010 from: http://www.indg.in/e-governance/e-governance/egov-plan

Raji, P.R. \& Arun, M. (2009). Gender Experiences in IT@School, an ICT-enabled education project of Kerala. Community Informatics: A Global e-journal, 6(1). Retrieved December 7, 2011 from: http://ci-journal. net/index.php/ciej/article/view/534/514

Schlager, E. \& Ostrom, E. (1992). Property rights regimes and natural resources: A conceptual analysis. Land Economics, 68(3): 249-262.

Software Principles for the Public Sector with focus on Public Education, February 1-2, 2010, Bengaluru, Workshop Report.

Waring, T. \& Maddocks, P. (2005). Open source software implementation in the UK public sector: Evidence from the field and implications for the future. International Journal of Information Management, 25: 411-428.

Wenger, E., McDermott, R. \& Snyder, W.M. (2002). Cultivating Communities of Practice. Boston: Mass.: Harvard Business School Press.

Workshop on 'Public Software for Social Sector - Principles and Practice', Jaipur, February 2010. IT for Change. Retrieved, February 1, 2011 from: http://www.itforchange.net/wksp-jaipur

Pradip Ninan Thomas

PhD, Associate Professor

School of Journalism \& Communication

University of Queensland, Brisbane, Australia

Pradip.thomas@uq.edu.au 